\title{
FROST RESISTANCE OF CONSTRUCTION COMPOSITES DURING ONE-SIDED FREEZING
}

\author{
${ }^{1}$ Nepomyashchy O.M., Assistant, \\ lottor27@gmail.com, ORCID 0000-0002-0281-0598 \\ ${ }^{1}$ Vyrovoy V.M., Doctor of Engineering, Professor, \\ vyrovoy@ukr.net, ORCID 0000-0001-8818-4112 \\ ${ }^{1}$ Makarova S.S., Ph.D., Assistant Professor, \\ svetlana.unay@ukr.net, ORCID 0000-0003-3237-1431 \\ ${ }^{1}$ Khomenko A.A., Ph.D., Senior Lecturer, \\ destiny_soul@mail.ru, ORCID 0000-0003-2580-9861 \\ ${ }^{1}$ Odessa State Academy of Civil Engineering and Architecture \\ 4, Didrichson st., Odessa, 65029, Ukraine
}

\begin{abstract}
The presentation of the design in the form of an open, complex, self-organized system allows analyzing the influence of external influences on the reaction of its individual elements of the structure and the system as a whole. The freezing-thawing cycles are continuously selected from the range of external influences. These actions are the most dangerous for changing the structure of construction composites.

The conducted analysis of climatic conditions in the Odessa region for a period of 13 years showed that in one year, on average, there are more than 60 temperature transitions through $0^{\circ} \mathrm{C}$. In this regard, for the regions of the South of Ukraine ensuring the frost resistance of construction composites is relevant, economically justified task.

Currently, there are quite a number of hypotheses explaining the reasons for the decline in the basic properties of building materials when they are repeatedly frozen and thawed. According to DSTU B B.2.7-47-96 frost resistance test is normalized to be carried out in chemically aggressive environments and to take into account the operating scenario.

The work done has made it possible to evaluate the effect of freezing conditions on the change of their physical-mechanical characteristics and frost resistance of building materials.

The analysis of the experimental results showed that with the increase in the number of cycles in the samples of cement and mortar, structural changes occur that depend on the conditions of freezing. This is evidenced by changes in such indicators as: mass, water absorption, speed of ultrasound, coefficients of damage and depth of carbonation. Structural changes cause changes in strength, both in samples of cement stone and of cement-sand mortar.

The experimental results obtained suggest that the conditions of influence of negative temperatures on products and structures play a significant role in their ability to resist frost damage. Further studies have been developed to reveal the causes of the phenomenon.
\end{abstract}

Keywords: material properties, local freezing and thawing, structural changes.

Introduction. Representation of the structure in the form of an open complex self-organized system allows to analyze the influence of external effects on the reaction of individual elements of the structure and the system as a whole. Continuously repeating cycles of freezing and thawing are distinguished from the range of external influences effects. These influences are the most dangerous for changing the structure of building composites.

Existing methods of the frost resistance assessment of building materials are based on the assumption that after wetting samples are subjected to complex influence of negative temperatures. An analysis of the operating conditions of most construction products and structures (enclosing structures of buildings and constructions of various values, dams, canal lining, pressure and nonpressure pipes, power lines, etc.) showed that, as a rule, external climatic loads act on them onesided or locally. It can be assumed that under these types of influences, the behavior of materials in 
products will significantly differ from their behavior during comprehensive freezing. For a more objective assessment of frost resistance, the relevant task is to analyze the conditions of the external influence of negative temperatures on the changing of the physic-mechanical characteristics of mortars and concrete.

Analysis of recent research. The analysis of climatic conditions in the Odessa region over a period of 13 years showed that in the autumn-winter season, on average, more than 60 temperature transitions through $0{ }^{\circ} \mathrm{C}$ are observed. Concerning this, for the regions of southern Ukraine, ensuring the frost resistance of building composites is a relevant, economically viable task.

Most experts refer stresses and strains that occur in pores and capillaries from freezing water to the main reasons for reducing the frost resistance of concrete, as capillary-porous bodies.

Currently, there is a fairly large number of hypotheses that explain the reasons for the decreasing of basic properties of building materials during their repeated freezing and thawing. The analysis of scientific and technical literature allowed to identify the main hypotheses of reducing the materials frost resistance.

The most common hypothesis was proposed by T.S. Powers. He suggested that frost damage only occurs when the hydraulic pressure associated with the displacement of fluid from the capillary exceeds the tensile strength of concrete. The value of the hydraulic pressure depends, first of all, on the length of the path traveled by the displaced water to the nearest free space for expansion (the reserve pores). This position was supported by Sheikin A.E., Dobshits L.M., Dvorkin L.I., Stark I., Moskvin V.M., Kapkin M.M., Mazur B.M. and others.

A.M. Podvalniy [1] proposed a model of frost destruction mechanism, based on which the capillary and shell are considered as a thick-walled pipe with a variable ratio of shell and capillary radii. When considering a single capillary, the effect of neighboring capillaries is replaced by a uniformly distributed load on the outer surface of the shell. In addition, the difference in the coefficients of thermal deformation of the matrix and the aggregate [2-4] reduces frost resistance.

Particular attention is paid to the hypothesis, which is based on the direct effect of crystallizing ice on the walls of pores and capillaries. According to calculations, the ice pressure during water freezing is about $12 \mathrm{MPa}$, while concrete tensile strength rarely exceeds $7 \mathrm{MPa}$, which leads to concrete destruction. Destruction increases with each cycle of freezing and thawing.

One hypothesis is based on the dependence of the freezing point on pore size. During the cooling process, water first freezes in large capillaries and pores, while in smaller gel pores it remains in a liquid state. Since the vapor pressure above water is higher than that above the ice, a thermodynamic nonequilibrium state arises, which creates a force for moving water from smaller to larger pores or onto the ice-covered concrete surface.

Wilhelm Pfeffer discovered the effect of osmosis, studying the metabolism and conversion of energy in plants. This effect found its application in building materials science, which allowed to propose a hypothesis of pore fluid concentration boundary influence on the frost resistance.

According to [5], in the structure of cement stone and concrete there are technological cracks (TC) and internal partition surfaces (PS) of various scale levels. When free water freezes in the volume of pores, capillaries and cracks, ice pressures their walls, which leads to the internal volume increasing and tensile deformations in the mouth area development.

According to DSTU B V.2.7-47-96, the frost resistance test is normalized to be carried out in chemically aggressive environments and the operating scenario should be taken into account. In operating scenarios that are considered by DSTU there are no one-sided environmental impacts. After analyzing the literature and operating conditions, it was suggested that one-sided (local) impact is one of the most common types of impacts on the structure.

The analysis of the main reasons for the frost resistance decreasing showed that there is practically no scientific and technical information on the influence of the freezing conditions of products (samples) on the ability of a material to perceive the deformations development if the volume of freezing water increases without destruction. The condition of structure freezing means the conditions of negative temperatures impacting the product. Two characteristic ways of freezing the product can be distinguished. The first method is to freeze the entire pre-wetted sample. This 
method has been used for more than a hundred years as a basic method for quantifying frost resistance of building materials of various types and purposes. The study of operating conditions made it possible to establish that most products perceive negative temperatures on individual surfaces (one-sided freezing). Changing the conditions of freezing significantly changes the formation of the freezing front, which leads to changing the internal heat and mass transfer, pinching or displacement of the gas component, the occurrence and development of moisture and temperature deformations, etc. This suggests that a change in the freezing conditions of the samples (comprehensive or one-sided) should lead to a change in the frost resistance of building materials. Thus, taking the method of freezing samples into account will allow a more objective assessment of the frost resistance of the material and the development of appropriate prescription-technological methods to increase the resistance of materials depending on the type and operating conditions of the products and structures.

Goal and tasks. The purpose of the work was to determine the effect of various types of influences of negative temperatures on the structure. The objective of the study was to assess the effect of comprehensive and one-sided freezing of samples on changes in the physic-mechanical characteristics and frost resistance of building materials.

Objects and research methods. The objects of study and analysis are beam samples $(40 \times 40 \times 160 \mathrm{~mm})$ made of cement stone $(\mathrm{W} / \mathrm{C}=0.27)$ and cement-sand mortar $($ cement $/ \mathrm{sand}=1 / 2$ and $\mathrm{W} / \mathrm{C}=0.5$ ).

Each type of sample was divided into three groups.

The first group (O1) includes samples that were tested in accordance with DSTU B V 2.7-42-97.

The second group $(\mathrm{O} 2)$ includes samples that were tested under conditions of one-sided freezing-thawing. Visually, the sample was divided into two halves. One half that was in thermal insulation $(\mathrm{O} 2+)$, and the other one was exposed to freeze-thaw cycles (O2-), Fig. 1.

The third group (O3) includes samples that were maintained in a normal hardening chamber with a humidity of $95 \%$.

After every five cycles of freezing and thawing, samples of all three groups were checked for the following characteristics: mass $(\Delta \mathrm{m})$, water absorption $(\mathrm{w})$, ultrasound transmission rate $(v)$, damage coefficient $\left(\mathrm{K}_{\mathrm{dc}}\right)$, bending tensile strength $\left(\mathrm{f}_{\mathrm{ctk}}\right)$, strength under compression $\left(\mathrm{f}_{\mathrm{ck}}\right)$, carbonation depth.

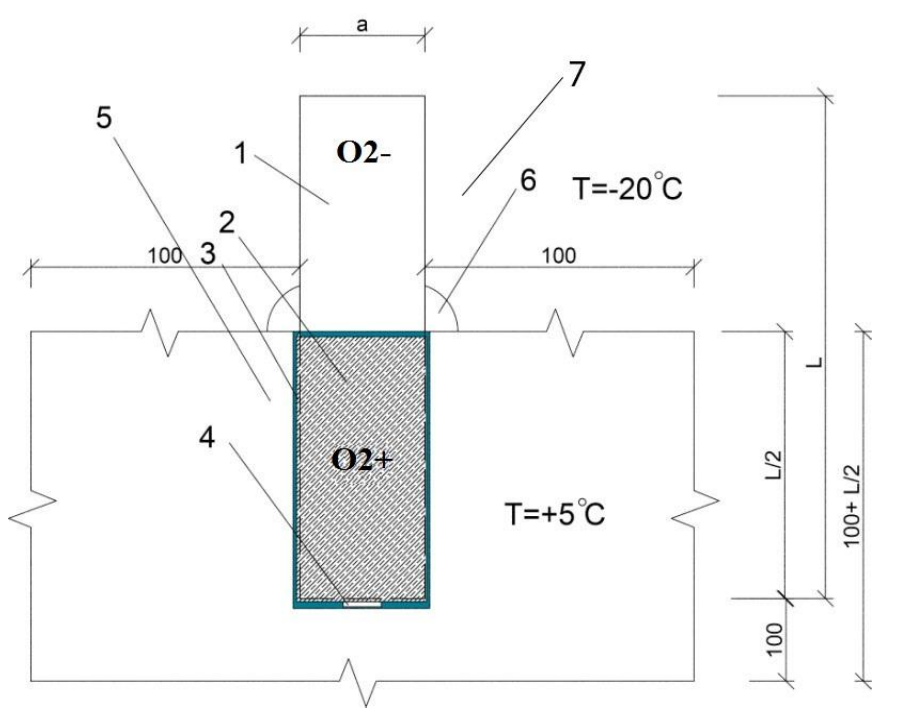

1 - part of the sample that was undergone to freeze-thaw cycles; 2 - part of the sample, which was maintained in the positive temperature range;

3 - thermal insulation $5 \mathrm{~mm}$ thick; 4 - temperature sensor; 5 - styrofoam ; 6 - medical cotton wool; 7 - freezer.

Fig. 1. Example of sample preparation for one-sided freeze-thaw tests

The results of the study. With comprehensive freezing, a kind of «freezing front» is formed, which contributes to the displacement of free water into the deep layers of the material. Since building materials on an inorganic binder are represented as capillary-porous medium, the formation of an integral freezing front is associated with processes and phenomena that occur in individual pores and 
capillaries. The soil freezing hypotheses were proposed and analyzed by professor Sumgin M.I. in the 1930s [6] when studying the processes of soil freezing in permafrost areas. He considered the soil model as a kind of dispersed system, the properties of which depend on the nature and level of interactions of individual particles of the dispersed phase with each other and with the dispersion medium (water). When water freezes in the pore space of this kind system, the volume increasing of system water is proportional to the volume change of free water. Thus, the portion of the disperse system that has been exposed to negative temperature, increases in volume, which causes the transfer of part of the volumetric deformations to other layers of the system. Analyzing the mechanism of this process, it is logical to conclude that as a result of a one-sided volume increase, uniform pressure arises, which leads to the fact that the freezing part of the system, like a piston, presses on the deep layers, forcing some of the free water deep into the system.

Historically, such a mechanism of water displacement was accepted as the main one when describing the processes occurring in a separate capillary. This is the basis for the hypothesis of reducing the frost resistance of building materials, and the formulation and technological measures are being developed to create the so-called reserve porosity for water flow displaced when it freezes in capillaries volume. If taking a similar mechanism of internal heat and mass transfer as a basis, then under the conditions of comprehensive freezing, a significant amount of water will be concentrated in the deep zones of the samples (products), forming the «core» of the material supersaturated with moisture. With complete freezing, the pressure that occurs with a water volume increase should lead to the destruction of the sample (product) from the inside. For the entire period of observation of building products and structures behavior and when studying frost resistance on individual samples, the explosive nature of the destruction was not described by the method «from inside to outside». As a rule, the destruction of samples during comprehensive and periodic freezing and thawing occurs from the surface layers to the deep layers of the material. The cause of destruction can be the gradients of volumetric deformations in the sample during its freezing and thawing, as well as a complex of mechanisms occurring in different-sized pores and capillaries taking into account different coefficients of thermal deformations of individual components.

Under conditions of one-sided freezing, part of the sample (product) is almost always in the zone of positive temperatures. Therefore, periodic freezing-thawing undergoes a part of the material located in the zone of influence of negative temperature. It was shown in $[7,8]$ that when water freezes in capillaries, their volume increases, which leads to additional saturation with moisture. This suggests that with one-sided freezing, significant mass transfer should not occur. When the temperature decreases to negative values, two multidirectional processes occur: a decrease in the volume of the solid component of the material with a simultaneous increase in the volume of the sample due to an increase in the volume of water when it freezes in the pores and capillaries of the material.

Alternating volumetric deformations of the material, arising due to periodic changes in temperature and ice pressure, lead to structure changing, which, in turn, changes the physic-mechanical properties of cement stone and concrete, which are in the zones of negative temperatures. Experimental studies have shown that with increasing the number of cycles, the water absorption of $\mathrm{O} 1$ samples from cement stone increases by $24 \%$ (from $13.5 \%$ to $16.7 \%$ ), and $\mathrm{O} 2$ increases by $20 \%$ (from $13.5 \%$ to $16.2 \%$ ), while control samples reduced water absorption by $4.3 \%$ (from $14 \%$ to $13.4 \%$ ).

The water absorption of mortar samples remains almost unchanged during the first 20 cycles of one-sided and comprehensive freezing and thawing. A subsequent increase in the number of cycles leads to decrease in water absorption to $18 \%$ with one-sided freezing and up to $25.4 \%$ with comprehensive freezing. A decrease in water absorption with an increase in the number of cycles can be associated with crystallization of salt in the capillary-porous space of mortar samples.

The change in water absorption with repeated changes in temperature indicates a change in the pore structure, which is indirectly confirmed by the results on an increase in the speed of ultrasound with an increase in cycles. Structural transformations are confirmed by the results on the effect of freezing conditions on the depth of carbonization - with comprehensive freezing, the carbonization depth is more than twice higher than the carbonization depth of samples that were 
subjected to one-sided freezing. By changing the damage factors, we can quantitatively assess the effect of freezing conditions on the change in the structure of cement stone and mortar. The experiments showed that with increasing in the number of cycles increases the value of $\mathrm{K}_{\mathrm{dc}}$. In this case, the damage to the samples upon comprehensive freezing and thawing is on average $22 \%$ higher than the damage to the samples due to one-sided impact of negative temperature. It can be concluded that a change in the freezing conditions inevitably affects an appropriate change in the structure of the samples. In it's turn, a change in structure leads to a change in the strength characteristics of cement stone and mortar.

The experiments showed that for samples from a cement-sand mortar the strength $\mathrm{f}_{\text {ctk }}$ after 20 cycles of comprehensive freezing decreased almost twice, and by $18 \%$ under one-sided impact of negative temperatures, Fig. 2, a. The decrease in $f_{\mathrm{ck}}$ strength for mortar samples, after 20 cycles, under comprehensive freezing conditions was $28 \%$, while the change in freezing conditions led to a decrease in $\mathrm{f}_{\mathrm{ck}}$ by $10 \%$ in half of the $\mathrm{O} 2+$ sample and by $7 \%$ in $\mathrm{O} 2-$, Fig. 2 , b.

With an increase in the number of cycles to 40 , the overall picture of the effect of freezing conditions on the change in the strength characteristics of samples from a cement-sand mortar is preserved, Fig. 2, a, b.

a)

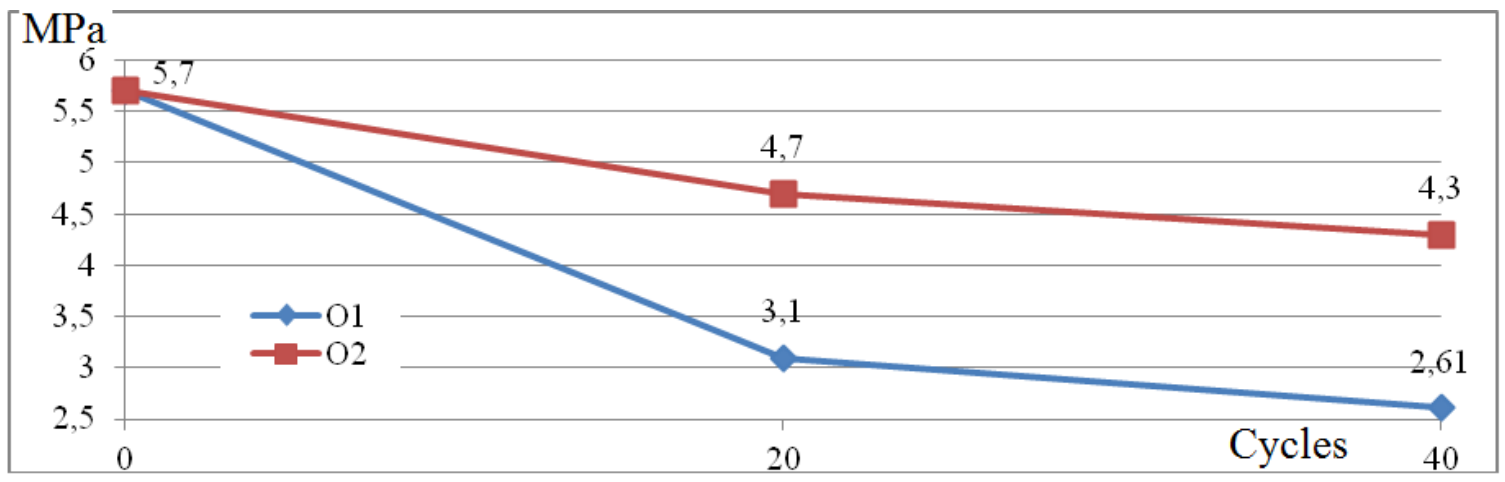

b)

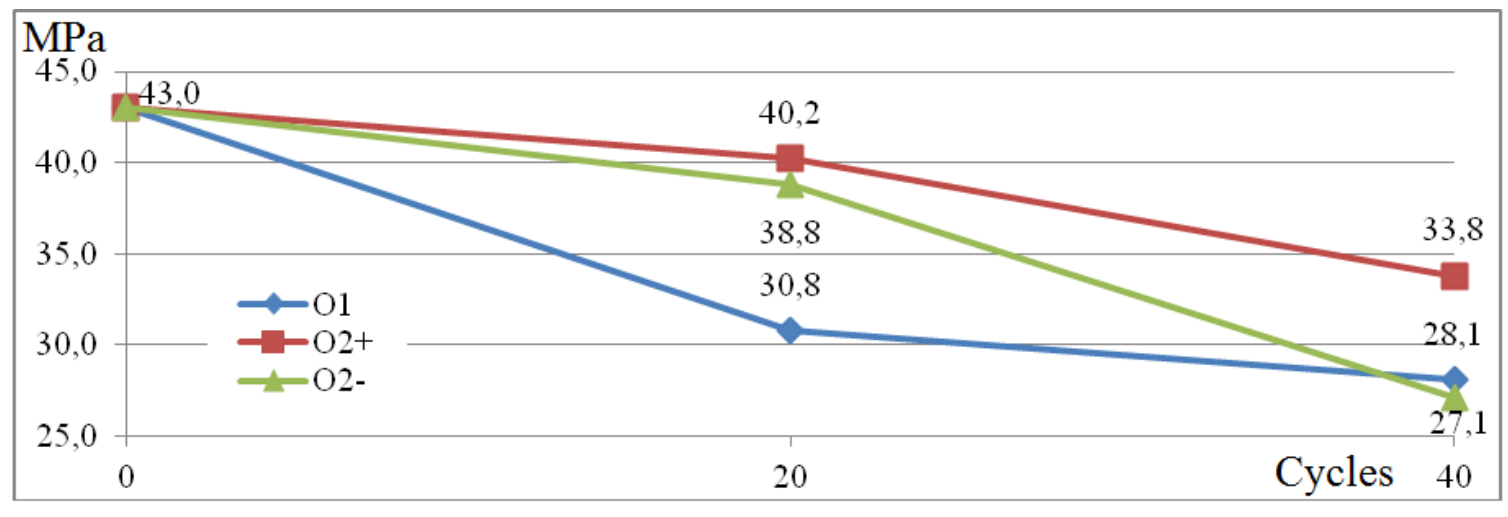

Fig. 2. The effect of freezing conditions on the change in the mechanical characteristics of cement-sand mortar: $\mathrm{a}-\mathrm{f}_{\mathrm{ctk}} ; \mathrm{b}-\mathrm{f}_{\mathrm{ck}}$

Also, this picture is preserved on samples of cement stone after 20 cycles of freezing and thawing. The strength of the $\mathrm{f}_{\mathrm{ctk}}$ for comprehensive impact has more than halved and is reduced by $44 \%$ with one-sided freezing. For comprehensive freezing, the strength $\mathrm{f}_{\mathrm{ck}}$ decreased by $43 \%$ and by $26 \%$ under one-sided exposure to negative temperatures in half $\mathrm{O} 2+$ and by $37 \%$ in $\mathrm{O} 2-$, Fig. 3 , a, b.

Studies have shown a significant effect of freezing conditions on the change in the physicmechanical properties of cement stone and cement-sand mortar. It can be assumed that one-sided freezing creates more favorable situations in the samples that can relax part of the dangerous deformations that occur when water freezes in the pore volume of the material. 


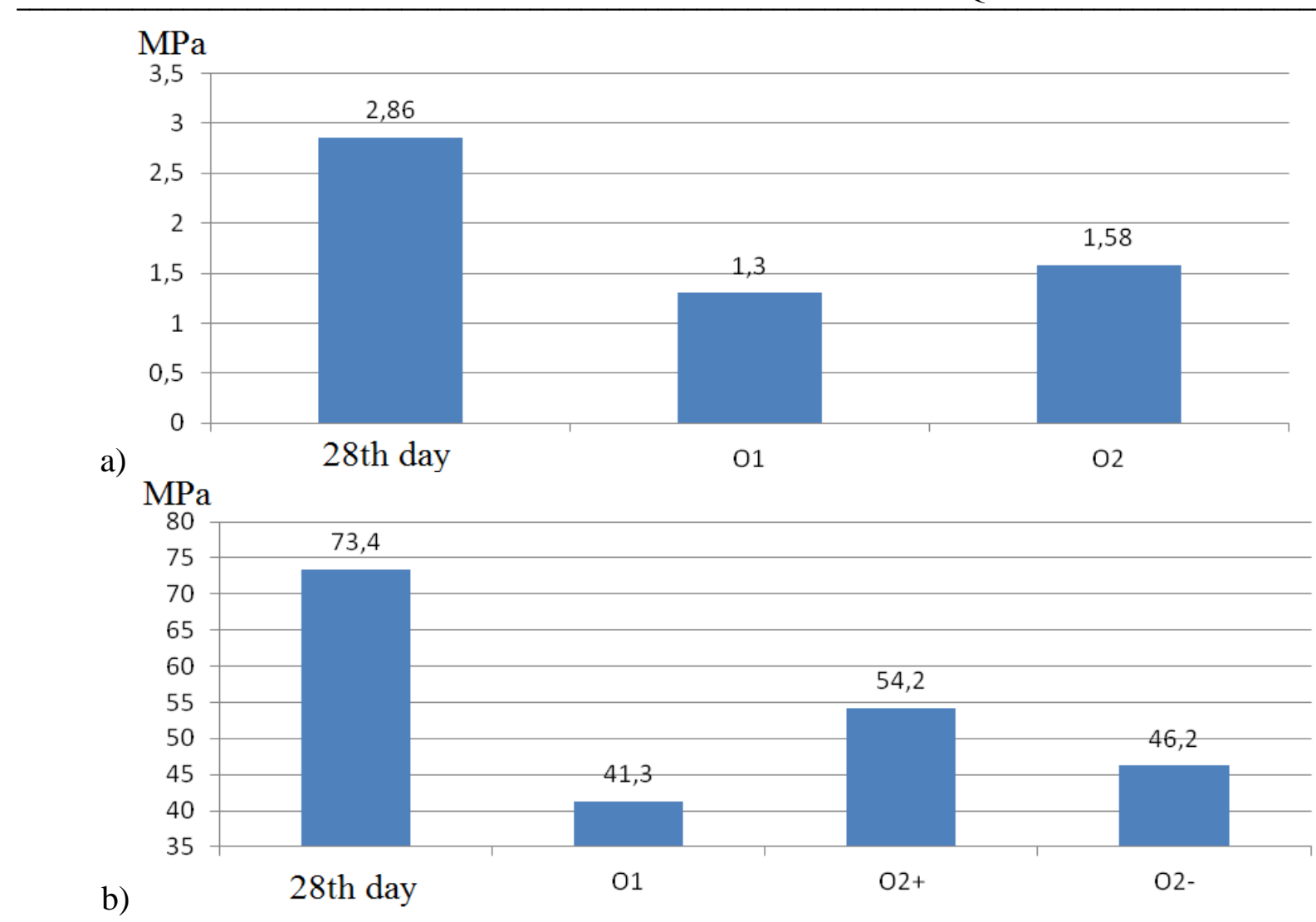

Fig. 3. The influence of freezing conditions on the change in the mechanical characteristics of cement stone (after 20 exposure cycles): $\mathrm{a}-\mathrm{f}_{\mathrm{ctk}} ; \mathrm{b}-\mathrm{f}_{\mathrm{ck}}$

An analysis of the experimental results showed that with an increase in the number of cycles in samples of cement stone and mortar, structural changes occur that depend on the conditions of freezing impact. This is evidenced by a change in such indicators as: mass, water absorption, ultrasound transmission speed, damage factors and carbonization depth. Structural changes cause changes in the strength characteristics both in samples of cement stone and in cement-sand mortar.

Conclusions. The work done made it possible to evaluate the effect of comprehensive and one-sided freezing of samples on the change in the physic-mechanical characteristics and frost resistance of building materials.

Experimental studies have shown that with one-sided freezing, the change in mass, carbonization depth, damage coefficients, and physical and mechanical characteristics is less intense compared to the comprehensive impacts of negative temperatures.

The obtained experimental results suggest that the conditions of the effect of negative temperatures on products and structures play a significant role in their ability to resist frost damage. To reveal the causes of the manifestation of the discovered phenomenon, further research programs have been developed.

\section{References}

[1] A.M. Podval'nyj, "O sobstvennyh napryazheniyah, voznikayushchih $\mathrm{v}$ betone pri zamorazhivanii", IFJ, no 2, T. XXV, pp. 316-324, 1973.

[2] G.I. Gorchakov, N.I. Lifanov, L.N. Terekhin, Koefficienty termicheskogo rasshireniya $i$ temperaturnye deformacii stroitel'nyh materialov. M.: Izdatel'stvo komiteta standartov, mer i izmeritel'nyh priborov pri Sov. Min. SSSR, 1968.

[3] YU.V. Osetinskij, A.M. Podval'nyj, "O vybore modeli dlya rascheta sobstvennyh napryazhenij v betone", Mekhanika kompozitnyh materialov, no 5, pp. 789-796, 1982.

[4] O.V. Kuncevich, Betony vysokoj morozostojkosti dlya sooruzhenij Krajnego Severa. L.: Strojizdat, 1983.

Bulletin of Odessa State Academy of Civil Engineering and Architecture, 2020, no. 79, page 109-116 
[5] V.N. Vyrovoj, V.S. Dorofeev, V.G. Suhanov, Kompozicionnye stroitel'nye materialy $i$ konstrukcii, struktura, samoorganizaciya svojstva. Odessa: «TES», 2010.

[6] M.I. Sumgin, Vechnaya merzlota pochvy v predelah SSSR: monografiya. MoskvaLeningrad: Izdatel'stvo Akademiya nauk SSSR, 1937.

[7] A.A. Homenko, P.S. Rogozha, T.V. Ostra, "Razvitie gradientov vlazhnostnyh deformacij v neravnomerno uvlazhnennyh konstrukciyah", Visnik Odes'koï derzhavnoï akademiï budivnictv ta arhitekturi, vol. 55, pp. 286-293, 2014.

[8] V.N. Vyrovoj, N.O. Zakorchemnaya, YU.O. Zakorchemnyj, "Analiz mekhanizma razvitiya treshchin pri zamerzanii v ih ob"eme vody", Visnik DonNABA. Suchasni budivel'ni materiali. Kompozicijni materiali dlya budivnictva, no. 63, pp. 96-100, 2007.

\title{
МОРОЗОСТІЙКІСТЬ БУДІВЕЛЬНИХ КОМПОЗИТІВ ПРИ ОДНОСТОРОННЬОМУ ЗАМОРОЖУВАННІ
}

\author{
${ }^{1}$ Непомящий О.М., асистент, \\ lottor27@gmail.com, ORCID 0000-0002-0281-0598 \\ ${ }^{1}$ Вировой B.М., д.т.Н., професор, \\ vyrovoy@ukr.net, ORCID 0000-0001-8818-4112 \\ ${ }^{1}$ Макарова С.С., к.Т.н., доцент, \\ svetlana.unay@ukr.net, ORCID 0000-0003-3237-1431 \\ ${ }^{1}$ Хоменко А.О., к.т.н., ст. викладач, \\ destiny_soul@mail.ru, ORCID 0000-0003-2580-9861 \\ ${ }^{1}$ Одеська державна академія будівництва та архітектури \\ вул. Дідріхсона 4, м. Одеса, 65029, Україна
}

Анотація. Подання конструкції у вигляді відкритої складної системи, що самоорганізується, дозволяє проаналізувати вплив зовнішніх впливів на реакцію окремих елементів іiі структури та системи в цілому. 3 гамми зовнішніх впливів виділені цикли заморожування та відтаювання, що безперервно повторюються. Ці цикли $є$ найбільш небезпечними для зміни структури будівельних композитів.

Проведений аналіз кліматичних умов в Одеській області за період 13 років показав, що за один рік, в середньому, спостерігається більше 60 переходів температури через $0^{\circ} \mathrm{C}$. У зв'язку з цим, для регіонів Півдня України забезпечення морозостійкості будівельних композитів є актуальним, економічно виправданим завданням.

В даний час існує досить велика кількість гіпотез, що пояснюють причини зниження основних властивостей будівельних матеріалів при їх багаторазовому заморожуванні та відтаванні. Згідно ДСТУ Б В.2.7-47-96 випробування на морозостійкість нормується проводити в хімічно агресивних середовищах і враховувати сценарій експлуатації.

Результати експериментальних даних дали можливість оцінити вплив умов заморожування на зміну фізико-механічних характеристик і морозостійкості будівельних матеріалів.

Аналіз експериментальних результатів показав, що зі збільшенням кількості циклів у зразках з цементного каменю і розчину, відбуваються структурні зміни, які залежать від умов впливу заморожування. Про це свідчить зміна таких показників як: маси, водопоглинення, швидкості проходження ультразвуку, коефіцієнтів пошкодженості та глибини карбонізації. Структурні зміни викликають зміни міцності, як в зразках 3 цементного каменю, так і з цементно-піщаного розчину.

Отримані експериментальні результати дають підставу зробити висновок, що умови впливу негативних температур на вироби і конструкції грають істотну роль в їх здатності чинити опір морозному руйнуванню. Для розкриття причин прояву виявленого феномена розроблені програми подальших досліджень.

Ключові слова: властивості матеріалу, локальне заморожування і відтавання, структурні зміни. 


\title{
МОРОЗОСТОЙКОСТЬ СТРОИТЕЛЬНЫХ КОМПОЗИТОВ ПРИ ОДНОСТОРОННЕМ ЗАМОРАЖИВАНИИ
}

\author{
${ }^{1}$ Непомящий А.Н., ассистент, \\ lottor27@gmail.com, ORCID 0000-0002-0281-0598 \\ ${ }^{1}$ Выровой В.Н., д.Т.Н., профессор, \\ vyrovoy@ukr.net, ORCID 0000-0001-8818-4112 \\ ${ }^{1}$ Макарова С.С., к.т.н. доцент, \\ svetlana.unay@ukr.net, ORCID 0000-0003-3237-1431 \\ ${ }^{1}$ Хоменко А.А., к.т.н., ст. преподаватель, \\ destiny_soul@mail.ru, ORCID 0000-0003-2580-9861 \\ ${ }_{1}^{1}$ Одесская государственная академия строительства и архитектуры \\ ул. Дидрихсона 4, г. Одесса, 65029, Украина
}

\begin{abstract}
Аннотация. Представление конструкции в виде открытой, сложной, самоорганизующейся системы позволяет проанализировать влияние внешних воздействий на реакцию отдельных элементов ее структуры и системы в целом. С гаммы внешних воздействий выделены непрерывно повторяющиеся циклы замораживания и оттаивания. Эти циклы являются наиболее опасными для изменения структуры строительных композитов.

Проведенный анализ климатических условий в Одесской области за период 13 лет показал, что за один осенне-зимний сезон, в среднем, наблюдается более 60 переходов температуры через $0{ }^{\circ} \mathrm{C}$. В связи с этим, для регионов Юга Украины обеспечение морозостойкости строительных композитов является актуальной, экономически оправданной задачей.

В настоящее время существует достаточно большое количество гипотез, объясняющих причины снижения основных свойств строительных материалов при их многократном замораживании и оттаивании. Согласно ДСТУ Б В.2.7-47-96, испытания на морозостойкость нормируется проводить в химически агрессивных средах и учитывать сценарий эксплуатации.

Результаты экспериментальных данных позволили оценить влияние условий замораживания на изменение физико-механических характеристик и морозостойкости строительных материалов.

Анализ экспериментальных результатов показал, что с увеличением количества циклов в образцах из цементного камня и раствора происходят структурные изменения, которые зависят от условий воздействия замораживания. Об этом свидетельствует изменение таких показателей как: масса, водопоглощение, скорость прохождения ультразвука, коэффициент поврежденности и глубина карбонизации. Структурные изменения вызывают изменения прочности как в образцах из цементного камня, так и из цементно-песчаного раствора.

Полученные экспериментальные результаты дают основание сделать вывод, что условия воздействия отрицательных температур на изделия и конструкции играют существенную роль в их способности сопротивляться морозному разрушению. Для раскрытия причин проявления обнаруженного феномена разработаны программы дальнейших исследований.
\end{abstract}

Ключевые слова: свойства материала, локальное замораживание и оттаивание, структурные изменения.

Стаття надійшла до редакції 12.03.2020 